\title{
Visualisering som drivkraft i kunnskapskonstruksjon
}

\section{Undersøkt gjennom et Alrltografisk blikk}

\author{
Mari-Ann Letnes* \\ NTNU Norges teknisk-naturvitenskapelige universitet
}

\section{Sammendrag}

Gjennom arbeidet med denne artikkelen har hensikten vært å frembringe ny metodologisk kunnskap om hvordan visualisering kan ha en sentral rolle i kunnskapskonstruksjon, meningsskaping og meningskommunikasjon. Siktemålet med artikkelen er å beskrive og problematisere momenter som gjør seg gjeldende når en grafisk designer/forsker/lærer (a/r/tograf) visualiserer forståelser. I artikkelen undersøker jeg retrospektivt visuelle representasjoners plass i ulike prosjekter med blikk hentet fra a/r/tografens ulike identiteter. Slik frembringer jeg kunnskap om hvordan det visuelle kan drive kunnskapsprosjekter fremover, samt hvordan visuell meningskonstruksjon legger til rette for tenkning, refleksjon og kommunikasjon. I arbeidet med artikkelen har jeg også skapt tre nye visuelle representasjoner i den hensikt å vise hvordan jeg forstår, hvordan jeg undersøker, og en konseptualisering av det jeg fant.

Nøkkelord: A/r/tografi; kunstfaglig forskning; metodologi; visuell literacy

\begin{abstract}
The purpose of this article is to provide new methodological knowledge of how visualization can play a central role in knowledge construction, meaning making and communication. The aim of the article is to describe and problematize factors that make the debts when a graphic designer / researcher / teacher visualizes understandings. In the article, I do a retrospective examination of visual representations in different projects from an a/r/tographical perspective. In this way, I bring knowledge about how the visual can be a source of power for knowledge production, as well as how visual representations can facilitate thinking, reflection and communication. In the work with the article, I have also created three new visual representations for the purpose of showing how I understand, how I do research, and a conceptualization of what I found.
\end{abstract}

\section{Keywords: A/r/tography; art based research; methodology; visual literacy}

Received: May, 2017; Accepted: November, 2017; Published: December, 2017

^Korrespondanse: Mari-Ann Letnes, Institutt for lærerutdanning, NTNU, 7491 Trondheim. Epost: mari.ann.letnes@ntnu.no

(C) 2017 M. A. Letnes. This is an Open Access article distributed under the terms of the Creative Commons Attribution 4.0 International License (http://creativecommons.org/licenses/by/4.0/), allowing third parties to copy and redistribute the material in any medium or format and to remix, transform, and build upon the material for any purpose, even commercially, provided the original work is properly cited and states its license.

Citation: M. A. Letnes. "Visualisering som drivkraft $i$ kunnskapskonstruksjon undersøkt - gjennom et A/r/tografisk blikk». Fournal for Research in Arts and Sports Education, Special Issue: «A forske med kunsten» Vol. 1, 2017, pp. 112-130. 
Når forskere skriver frem sin forskning gjennom vitenskapelige fagtekster i ulike typer kommunikasjonskanaler, brukes ulike modaliteter i kommunikasjonen. I lingvistisk forstand handler modalitet om måten et meningsinnhold blir kommunisert på. Som mennesker skaper vi mening via og gjennom språket i ulike sosiale settinger (Halliday, 1978). Tradisjonell lingvistikk definerer språk som et system som er meningsskapende gjennom dobbel artikulasjon, hvor et budskap artikuleres både gjennom form og innhold. Måten innholdet kommuniseres på, er det vi kaller for modalitet (Kress \& Van Leeuwen, 2001). Modalitet er det tegnsystemet som brukes i et gitt kommunikativt uttrykk, for eksempel (verbal)språk, bilde, musikk og gester. Visuelle modaliteter omfatter blant annet skriftspråk, grafisk utforming, tegnspråk, gester, mimikk, fotografi, tegninger, maleri og film. Auditive modaliteter omfatter blant annet talespråk (inklusive prosodiske aspekter som tempo, trykk, stemmestyrke og toneleie), musikk og ringe- og alarmsignaler. Taktile modaliteter omfatter blant annet blindeskrift og berøring (stryking, klapping, dulting og slag). Ulike visuelle modaliteter er sentrale $\mathrm{i}$ forskning enten det er arbeid med foto, video eller malerier $\mathrm{i}$ kunsthistorien eller med å visualisere statistisk eller kvalitativ empiri. I de fleste forskningsmiljøer arbeider man med visuelle representasjonsformer, enten det er i medisinske laboratorier, på antropologiske feltarbeid, i kunstmuseer eller i astronomiske observatorier. En av grunnene til at forskere velger å bruke visuelle representasjoner, er at teorier eller empiri ikke nødvendigvis er fysiske og håndfaste, noe som gjør at forskere bruker teknologi, symbolske representasjoner og kreative uttrykk for å skape visuelle tolkninger og fremstillinger av disse (Trumbo, 1999).

Som forsker bruker jeg visuelle uttrykk for å konstruere egen forståelse gjennom alle delene av forskningsprosessen. Ved å gi liv til visuelle modeller, figurer, grafer, diagrammer og illustrasjoner har forskningens teoretiske innganger, metodologiske grep og de ulike forskningsprosjektenes kunnskapsbidrag som fokuseres i denne artikkelen, blitt konstruert og kommunisert i en veksling mellom verbal og visuell fremstilling. Med dette forstår jeg at visualisering i forskningsrapporter, artikler og avhandlinger ikke bare er illustrasjoner, men en kraft som driver forståelser og konseptualiseringer frem og i neste omgang kommuniserer og synliggjør denne nyervervede forståelsen for andre, slik at de på sin side kan konstruere egen forståelse. I forskningsformidling brukes som tidligere beskrevet modeller, analogier, ligninger, grafer, diagrammer, bilder og simuleringer presentert i mange forskjellige former verbalt, matematisk og visuelt (Lemke, 1998). Det har blitt gjennomført flere studier for å undersøke de enkelte representasjonene, men lite forskning er gjennomført for å finne ut hvordan multi-representasjonelle strategier fungerer. Tilsvarende er det gjort lite forskning på hvordan den transformative prosessen fra en representasjonsmåte til en annen kan øke den kognitive erkjennelsen (Yore \& Treagust, 2006, s. 308), altså kunnskapskonstruksjon gjennom re-mediering. Med bakgrunn i dette har følgende problemstilling vært retningsgivende for arbeidet i denne artikkelen:

Hvordan kan visualisering ha en sentral rolle i kunnskapskonstruksjon, meningsskaping og meningskommunikasjon? 


\section{A. Letnes}

For å undersøke problemstillingen har jeg metodologisk plassert meg innenfor Artbased research. Leavy (2009, s. 12) skriver at Arts-based research har utviklet metodologi for alle faser i forskning: datakonstruksjon, analyse, tolkning og formidling. I mitt første møte med forskningsprosjekter som masterstudent ble jeg overrasket over hvor lik forskningsprosessen er med den kreative prosessen jeg opplever som designer. Kunst og forskning er begge praksiser som forsøker å beskrive, forstå og forklare mennesket og menneskets væren. Grunnet i en undersøkende, analytisk og tolkende praksis arbeider kunstnere og forskere mot en avansert forståelse av menneskelig væren (Leavy, 2009). Med dette så kan det synes som kunstprosesser er ganske like forskningsprosesser (se Østern, 2017).

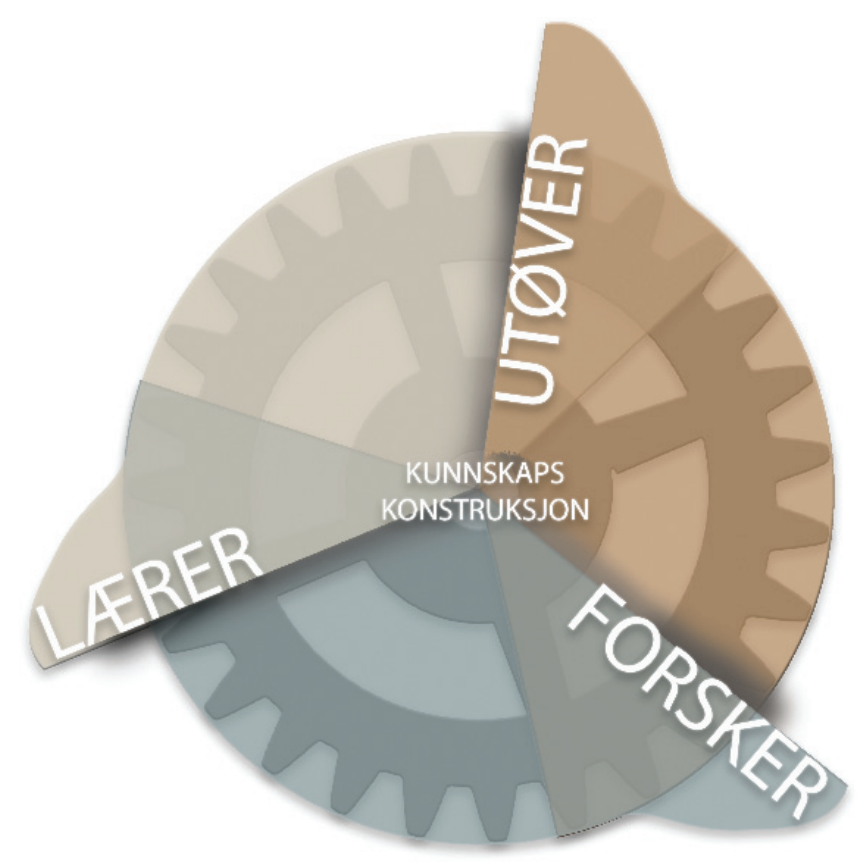

Figur 1. A/r/tografisk tannhjul. (Letnes, 2017)

\section{Empirikonstruksjon og analyse - fra erfaring til teoretisk forståelse}

Det har vært nærliggende for meg å undersøke kvaliteter knyttet til hvordan mening skapes når visuelle representasjoner blir konstruert og kommunisert, ut fra et (indre) deltagerperspektiv. Gjennom bruk av refleksiv metodologi (Alvesson \& Sköldberg, 2008) har jeg gjennomført en bevisst og analytisk selviakttagelse av egne erfaringer med det å skape visuelle representasjoner. Dette kan karakteriseres som en meta-analyse med undersøkelser på tvers av ulike praksiser. Metaanalysens hensikt har vært å undersøke hvordan det å skape visuelle representasjoner har fungert som en kraft som setter kunnskapskonstruksjon, kunnskapskonseptualisering, meningsskaping og meningskommunikasjon i bevegelse. For å undersøke disse bevegelsene har jeg valgt å ta utgangspunkt 
i a/r/tografens tre sentrale identiteter, nemlig artist, researcher og teacher. $\mathrm{A} / \mathrm{r} /$ tografi som metodologi er en av mange innganger Art-based research muliggjør. A/r/tografi er et sammenvevd trippelperspektiv i form av tre identiteter: utøveridentitet ( $\mathrm{a}=$ artist), forskeridentitet ( $\mathrm{r}=$ researcher) og læreridentitet ( $\mathrm{t}=$ teacher), eller tre praksiser: å skape, å forske og å undervise (Bendiksen, 2017; Springgay \& Irwin, 2005).

Jeg har skapt en visuell figur som jeg har valgt å kalle $\mathrm{A} / \mathrm{r} /$ tografisk tannhjul (se figur 1) for å synliggjøre hvordan de ulike identitetene eller praksisene fungerer som lameller, festet til et tannhjul, som setter kunnskap og forståelse i bevegelse. Figuren viser hvordan jeg gjennom disse tre praksisene erverver meg kunnskap i transformative prosesser via de tre identitetene utøver, forsker og lærer. En a/r/tografisk undersøkelse handler om å veve sammen ulike ståsteder, identiteter, posisjoner og metodologiske konsepter. I og med at de ulike identitetene iscenesettes og utspilles av en og samme person, gir de ulike perspektivenes spesifikke innsikt kunnskap til de andre identitetene. Springgay and Irwin (2005, s. 901) beskriver det slik:

To live the life of an artist who is also a researcher and teacher is to live a contiguous life, a life that dialectically moves between connecting and not connecting the three roles. The dialectical in/between spaces amid these roles are dynamic living spaces of inquiry: Spaces touching at the edges, then shifting to be close, adjacent, but not touching-only to touch again. It is not a process of categorization but a concept that requires deep attention and penetration.

De ulike identitetene jeg har, skaper bevegelse i tannhjulet (se figur 1), og alle erfaringene som gjøres er med på en samlet kunnskapskonstruksjon. De tre praksisene er med meg hele tiden, og på denne måten lever jeg i en evig undersøkende tilstand. Når jeg nå i ettertid går tilbake og ser på erfaringer jeg har gjort meg i mitt profesjonelle virke, trer de tre identitetene tydelig frem, noe som gjør det mulig retrospektivt å hente frem tre ulike eksempler på praksiser og omgjøre disse til et empirisk materiale. De tre a/r/tografiske eksemplene som har vært gjenstand for analyse i arbeidet med denne artikkelen, er:

A/r/tografisk eksempel 1. Sammenvevd visuell og verbal fremdrift, (forskeridentiteten løftes i forgrunnen)

A/r/tografisk eksempel 2. Felles mediering - en annen forskers øyne (utøveridentiteten løftes i forgrunnen)

A/r/tografisk eksempel 3. Iscenesetting av forskningsmetodisk forståelse hos masterstudenter (læreridentiteten løftes i forgrunnen)

Jeg kaller de tre eksemplene a/r/tografiske fordi jeg ønsker å belyse de tre identitetene utøveridentitet, forskeridentitet og læreridentitet. Selv om alle de tre identitetene hele tiden er en del av meg, er det alltid en av dem som plasserer seg i førersetet. Gjennom de valgte a/r/tografiske eksemplene har målet vært å legge grunnlag for en divergent empirisk inngang ved å bruke ulike typer av erfaringer med å designe visuelle representasjoner. Hensikten er å få frem et variert utvalg hvor forskeridentitet, utøveridentitet og læreridentitet får spille førstefiolin i hvert sitt a/r/tografiske eksempel. Det tre eksemplene er valgt ut med bakgrunn i hvordan det visuelle har vært med på å sette kunnskapskonstruksjonen i bevegelse på ulike måter. På denne 


\section{A. Letnes}

måten brukes tre spesifikke praksiser som eksempler for en metaanalyse på tvers, hvorpå det som er felles, er at det visuelle har vært en sentral inngang til forståelse og kunnskapskonseptualisering. Det er viktig å poengtere at disse tre eksemplene i utgangspunktet ikke er gjennomført som a/r/tografiske prosjekter. Det er blikket jeg har på eksemplene retrospektivt som er a/r/tografisk, da jeg ser at dette er identiteter som hele tiden er en del av meg og som på mange måter danner motoren i min virksomhet på tvers av mitt profesjonelle virke. For å rydde i tankene og for å konseptualisere denne metastudien ble tegnebrettet en hjelp, se Figur 2.

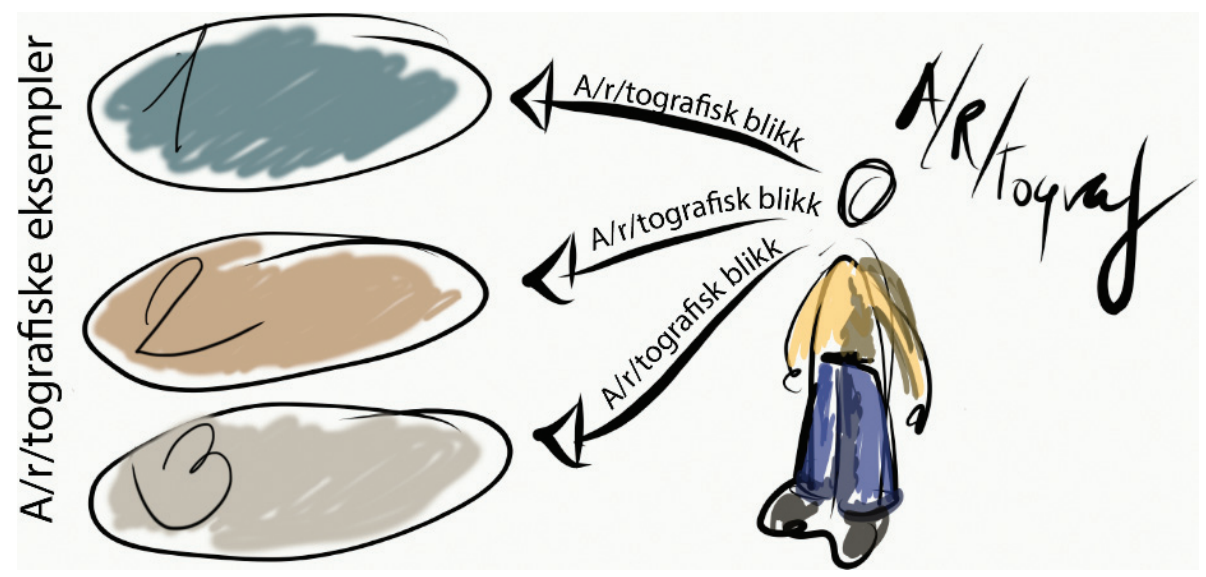

Figur 2. A/r/tografens blikk. (Letnes, 2017)

Metastudiens empiri utgjør med dette tre eksempler hvor jeg som a/r/tograf går tilbake og undersøker de forskjellige praksisene retrospektivt. Å gjennomføre en a/r/tografisk studie handler om å gjennomføre en undersøkelse gjennom en kontinuerlig prosess ved å skape artistiske uttrykk hvor det som skapes, ikke er separert fra skriving eller at uttrykket kun er en illustrasjon eller en representasjon av den skrevne teksten. Verbaltekst, og for min del, de visuelle representasjonene, er forbundet med hverandre og vevet sammen for å konstruere og kommunisere en utdypet forståelse.

Det er kun i en analyse at disse identitetene kan plukkes fra hverandre og belyses på denne måten. Dette er tre identiteter som alltid er med meg, og jeg kan ikke legge lokk på den grafiske designeren når jeg forsker eller underviser. Jeg er alt hele tiden, men jeg kan belyse og trekke en av dem i forgrunnen for å diskutere og drøfte hva det er som setter det hele i bevegelse. De tre ulike a/r/tografiske eksemplene danner på denne måten grunnlag for undersøkelse av hvordan visuelle representasjoner kan være og virke. De tre a/r/tografiske eksemplene undersøkes ikke i sin samtid, men i en retrospektiv undersøkelse. Dette er en vanskelig øvelse, og mye kan ha gått tapt med tiden. Det som imidlertid fortsatt finnes der, er de visuelle figurene, og dermed danner de visuelle artefaktene som ble skapt i de tre eksemplene, et empirisk materiale. I tillegg har jeg skrevet retrospektive refleksjoner rundt det jeg husker, knyttet til det å skape eller uttegne de ulike modellene. Disse kaller jeg retrospektive logger. 
Retrospektiv fortellerteknikk betyr at deler av teksten gir et tilbakeblikk på noe som har hendt tidligere. Retrospektiv, tilbakeskuende, handler om å belyse noe som har skjedd i fortiden. I en retrospektiv skriveteknikk starter jeg med slutten og går deretter tilbake i tid for å vise hva som ligger bak. På denne måten representerer de ferdige visuelle modellene slutten, mens de retrospektive loggene har til hensikt å nøste opp hva det var som gjorde at jeg endte opp med de visuelle representasjonene jeg gjorde. Med en slik tilnærming er målet å analysere og tolke empiri gjennom de tre ulike posisjoneringene grafisk designer/forsker/lærer i lys av teori, for så å utdype og utvikle teorien.

\section{Teoretisk bakteppe - visualisering og visuell literacy}

Visuelle representasjoner bør sees på som språk. Dette påpekte Barthes (1977) allerede første gang i 1964 i artikkelen Bildets retorikk. Artikkelen er utgitt flere ganger og har blitt stående som et viktig bidrag til hvordan en kan forstå meningsinnhold i bilder. I artikkelen arbeider Barthes blant annet med bildets og visuelle representasjoners to sider, nemlig konnotasjon og denotasjon (Barthes, 1977). Denotasjon er den direkte betydningen som viser til det saklige innholdet som ordet, tegnet/symbolet og bildet viser. Altså hva det konkret betyr. En figur kan «leses» ulikt fra person til person, altså gi ulike konnotasjoner. Konnotasjon er på mange måter det samme som assosiasjon, men forskjellen er at konnotasjoner er assosiasjoner som er felles for en gruppe mennesker. Det er den indirekte betydningen som viser til assosiasjoner som følelser, inntrykk og meninger man får ved å tenke på et ord, bilde eller tegn/symbol. Visuelle bilder, om det er grafiske figurer, fotografier, skulpturer eller konstruksjoner, er (re)presentasjoner av menneskelig kunnskap (Ricardo \& Joaquín, 2012). Det finnes mange ulike teoretiske innganger til det å skape visuelle representasjoner og kommunisere visuelt meningsinnhold, samtidig som undersøkelser knyttet til visuell kommunikasjon er multidisiplinære og multidimensjonale (Moriarty \& Kenney, 1995). Forfattere som skriver om dette temaet, kommer fra mediefeltet (herunder fotografering, reklame og nyheter på redaksjonelle områder), lærerutdanninger, media- og filmutdanninger, kunst og estetikk, antropologi, psykologi, filosofi, lingvistikk, semiotikk, arkitektur og til og med arkeologi (Moriarty \& Kenney, 1995). Dette mangfold av teoretiske og disiplinære innganger gir et rikt spekter av synspunkter og forståelser som er en ressurs på grunn av den innsikten som kommer på tvers av disse teoretiske og disiplinære feltene. Samtidig kan mangfoldet også føre til noen problemer når man skal undervise i det visuelle feltet på grunn av manglende enhetlig og felles teoretisk bakteppe (Moriarty \& Kenney, 1995).

Visualisering og andre visuelle ferdigheter er ansett for å være medfødt (Bradent \& Hortinf, 1982). Visuell literacy er evnen til å konstruere, tolke, forhandle og skape mening gjennom visuelle utrykk. Med andre ord handler det både om evne til å skape visuelle uttrykk og å tolke/lese visuelle uttrykk. Visuell literacy utvider betydningen av literacy/leseferdighet, noe som vanligvis betyr tolkning av en skriftlig eller trykt tekst. Begrepet "Visual Literacy» ble først brukt i 1969 av John Debes, en av de fremste og viktigste figurene i visuell literacy-feltets historie (Avgerinou \& Ericson, 1997). 


\section{A. Letnes}

Visuell literacy forstås med dette som evnen til å finne mening i visuelle uttrykk som bilder, grafiske representasjoner, diagrammer, illustrasjoner osv. Det innebærer et sett av ferdigheter som spenner fra enkel identifikasjon gjennom det å navngi det man ser, til komplekse tolkninger på kontekstuelle, metaforiske og filosofiske nivåer. Gjennom visuell tolkning blir mange aspekter av kognisjon brukt, som å assosiere, spekulere, analysere og kategorisere. Forståelse er forutsetningen for mye av denne kompetansen, men de subjektive og affektive aspekter av meningskonstruksjonen er like viktig. Ulike visualiseringsteknikker gir forskeren mulighet til å utforske, tolke og integrere ulike deler av forskningsprosessen for å gi rike og fleksible innganger til viten. På denne måten har visualisering to hensikter: For det første handler det om å tegne frem en forståelse. For det andre handler det om å kommunisere denne forståelsen gjennom ulike typer forskningsformidling, noe som gjør visualisering uunnværlig som erkjennelsesmetode, i hvert fall innen visse typer kunnskapsproduksjon.

Visuelle representasjoner i forskning vil kun fungere dersom de er delt mellom eksperter og iakttakere med en viss grad av visuell literacy. Det er problematisk å komme til enighet om hvordan man klart og presist kan presentere vitenskapelige ideer, prosesser eller funn (Trumbo, 1999). Moritary (1997) fremholder at en slik tilnærming plasserer premissene på læringsaspektet heller enn på kommunikasjons aspektet ved visuell literacy. Som et rammeverk for analyse av visuell literacy presenterer Trumbo (1999) tre konstruksjoner: visuell tenkning, visuell læring og visuell kommunikasjon. Visuell tenkning innebærer inkorporering av indre visuelle bilder som en del av måten å skape mening og kunnskap, å se for seg og forestille seg. Visuell tenkning innebærer også prosessen med å organisere mentale bilder ved hjelp av former, linjer, farger og komposisjoner for å gjøre dem meningsfulle (Wileman, 1980). Leonardo da Vinci var opptatt av at direkte observasjon var en inngangsport til oppdagelser; han kalte sine visualiseringsprosesser for saper vedere, "knowing how to see» (Boorstin, 1992). Forskning som er i en konseptualiseringsfase, krever ofte en aktiv visuell tenkning fra forskerens side (Trumbo, 1999). Denne formende eller skapende visualiseringen er en kreativ og intuitiv prosess som involverer en tett sammenveving av idégenerering og spørsmålsstilling Trumbo (1999). Visuell lering handler om hvordan vi bruker visuelle representasjoner i undervisning og hvordan visuell informasjon brukes i læreprosesser (Dwyer, 1972). Læreprosessen knyttet til visuelle representasjoner kan beskrives på mange måter (Trumbo, 1999). Trumbo presenterer en beskrivelse som er basert på Blooms (1956) taksonomi. Denne taksonomien omfatter tre domener: kognitiv, affektiv og psykomotorisk. Videre presenterer Bloom seks kategorier i det kognitive domenet (kunnskap, forståelse, anvendelse, analyse, syntetisering og evaluering). Disse kategoriene har Trumbo (1999) brukt for å definere og beskrive visuelle læringsstrategier. Visuell kommunikasjon handler om hvordan visuelle representasjoner blir brukt i den hensikt å kommunisere ideer og mening til andre (Wileman, 1980). I fortsettelsen vil rammeverket til Trumbo bli satt i dialog med de tre $\mathrm{a} / \mathrm{r} /$ tografiske eksemplene der visuell tenking, visuell kommunikasjon og visuell læring har fungert som strukturelle stoppunkter i teksten. 


\section{Tre a/r/t-ografiske eksempler}

A/r/t-ografisk eksempel 1 - Sammenvevd visuell og verbal fremdrift

Det a/r/tografiske eksempelet «Sammenvevd visuell og verbal fremdrift» er representert med forskningsprosjektet "Digital dannelse i barnehagen» (Letnes, 2014). I dette forskningsprosjekt fungerte jeg som forsker med eneansvar for prosjektets fremdrift. I tillegg til at jeg var forsker, var jeg også en forskningsdeltager i det jeg fungerte som barnehagelærer og veileder for de andre som arbeidet med de barna som deltok i prosjektet. I prosjektet vevdes det visuelle og verbale sammen i en felles fremdrift for å holde de ulike rollene synlige og tydelige for meg selv. I forskningsteksten knyttes den visuelle forståelsen sammen med den verbale forståelsen. På denne måten medieres en multimodal forståelse basert på visuelle og verbale konstruksjoner frem. I dette prosjektet var det spesielt tre visualiseringer som ble viktig for prosessens fremgang: forskningsdesign, analysestrategi og funn (teoribygging). Jeg har derfor skrevet retrospektive logger med fokus på hvordan viten blir konstruert og konseptualisert gjennom bruk av visuelle representasjoner i to av disse.

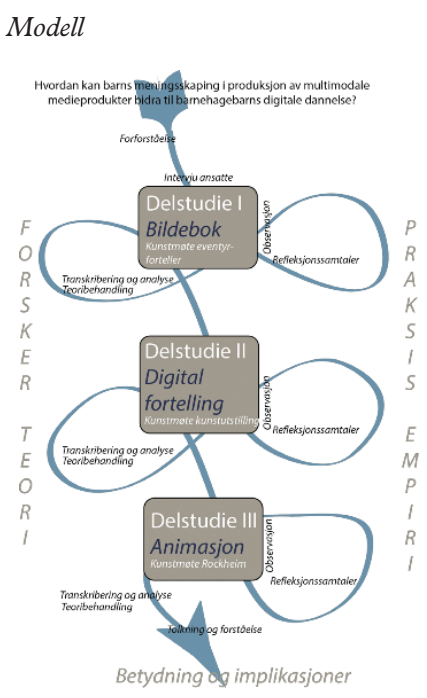

Figur 3. Forskningsdesign. (Letnes, 2014)

\section{Retrospektiv logg}

I dette forskningsprosjektet hadde jeg mange ulike empiriproduksjoner og flere ulike roller. Dette ga et komplekst metodisk design hvor jeg fikk behov for å tegne ut et kart slik at jeg kunne se hvordan de ulike elementene ble satt i spill.

I denne uttegningen ønsket jeg at møtet mellom forsker og praksis ikke skulle ligge i teoriene, men heller i praksis. Derfor tegnet jeg ut tre delprosjekter som en sentral stolpe i designet. På denne måten ble de tre delprosjektene og det som skjedde ute i praksisfeltet, det sentrale for kunnskapsproduksjonene. Videre har jeg tegnet sløyfer som piler gjennom de tre delprosjektene. Dette har til hensikt å visualisere hvordan det første delprosjektet påvirker og influerer delprosjekt 2. Ved at jeg tegnet ut dette designet, fikk forskningsprosjektet en klar retning, og selv med mange forskjellige roller visste jeg hele tiden hvilken hatt jeg hadde på meg. På denne måten kunne jeg tre inn og ut av ulike roller fordi jeg hele tiden visste hvor i kartet jeg befant meg. 


\section{A. Letnes}

Model

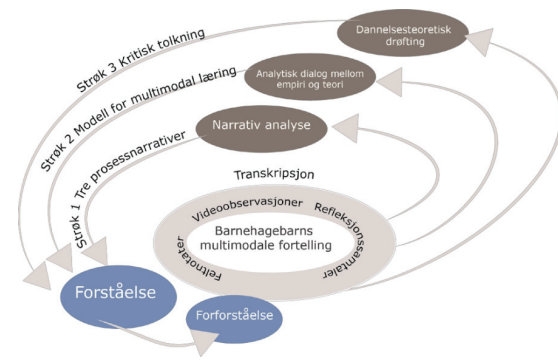

Figur 4. Analysedesign. (Letnes, 2014)
Retrospektiv logg

I analyse av det empiriske materialet i dette

forskningsprosjektet tok jeg utgangspunkt i en hermeneutisk bevegelse hvor jeg gradvis utdyper tolkningen fra en feltnær deskriptiv forståelse gjennom en teorimettet fremstilling til en kritisk forståelse i lys av et dannelsesteoretisk perspektiv. Dette ble en kompleks analyse med ulike bevegelser og transformasjoner gjort $\mathrm{i}$ den hensikt å frembringe viten. Med min visuelle oppmerksomhet tegnet jeg ut hvordan de ulike komponentene hang sammen. På denne måten fungerer analysedesignet som en måte å rydde opp i og konseptualisere min egen tenkning, fremgangsmåte og forståelse. Analysen ble tegnet frem med tre elliptiske strøk som hadde til hensikt å visualisere de sirkulære bevegelsene jeg hadde i analysen min. Den indre ellipsen visualiserer de tre delstudiene som ble giennomført ute i barnehagefeltet, med både prosess og produkt. Det empiriske materialet som ble generert i delstudiene, blir vist som tekst i den brune sirkelen. Den transkriberte empirien danner så grunnlaget for min forståelse av forskningsfenomenet gjennom en konstruksjon av tre prosessnarrativer. Videre kaster den hermeneutiske bevegelsen via multimodal, sosiokulturell læringsteori og kunstpedagogisk perspektiv lys over barnas meningsskaping i arbeid med egne multimodale fortellinger. Til sist diskuteres hvordan de kunstfaglige læreprosessene gjennom barnas kunnskapskonstruksjon fungerer som bidrag inn i barnas digitale dannelse i et kritisk tolkningsstrøk.

\section{Visuell tenkning - delaspekt av visualiseringens kraft}

Gjennom å tegne ut dette forskningsdesignet ble det tydelig for meg at møtet mellom forsker og praksis er et spennende møte. Selv med et komplekst prosjekt som dette kunne jeg som forsker holde mange baller i luften samtidig. Analysedesignet synliggiorde hvordan min egen kunnskap ble konstruert i sirkulære bevegelser. Å holde et analytisk kart vitalt gjennom en visuell bevissthet gjorde at de abstrakte tankene rundt analyse av empirien plasserte seg et sted i kroppen min. De tre analytiske strøkene kan sammenlignes med bevegelser jeg har når jeg maler ved å bruke pensel, maling og lerret. På samme måte som jeg med penselstrøk legger maling i lag på lag på et lerret for å skape et bilde, har de analytiske strøkene i forskningsprosjektet til hensikt å synliggiøre ulike analytiske innganger og behandling av empirien som er produsert. Ved å visualisere den analytiske prosessen tar den plass både som et konsept og en aktiv handling som materialiseres kroppslig i meg. 
Gjennom forskningsprosjektet «Digital dannelse i barnehagen» var den viktigste drivkraften for prosjektets fremdrift den visuelle konseptualiseringen jeg til stadighet gjorde. Gjennom å visualisere min forståelse av den lesningen jeg gjorde av teoretiske perspektiver og innganger, de metodologiske sammenhengene og fremstilling av det empiriske og analyserte materialet, fikk jeg hele tiden en fornemmelse av hvordan det hele hang sammen. Dette hjalp meg i min forståelse av det som skjedde i feltet. Jeg lagde et visuelt kart over det landskapet jeg vandret i. På denne måten tenkte jeg via visuelle konstruksjoner i alle delene av forskningsarbeidet. Videre brukte jeg de visuelle modellene og fremstillingene for å kommunisere multimodalt både via skriftspråk og det visuelle språket i forskningsteksten. På denne måten kan leseren også skape sine bilder av hvordan de ulike delene henger sammen.

Visuell tenkning involverer inkorporering av visuelle bilder som en del av bevisst og førbevisst tenkning (Wileman, 1980). Det førbevisste kan forklares som en kroppslig prosess, jeg kjenner at jeg er i ferd med å forstå noe, og da hjelper det alltid å sette seg ned med tegnebrettet. Ved tegnebrettet kan jeg tegne ut og tydelig se hva det er jeg forstår og hva det er som enda synes uklart. Det handler om å tegne frem et landskap som til dels er kjent og til dels er ukjent. Gjennom å tegne vokser en gryende og begynnende forståelse frem, og det hele materialiserer seg. I denne prosessen bruker jeg tidligere erfaringer for å forstå det som skjer her og nå. I dette er fortid, nåtid og fremtid samtidig til stede i en indre kamp med å gripe og begripe det jeg arbeider med. I prosessen med å bli bevisst det førbevisste, involveres en organisering av mentale bilder ved å bruke punkter, linjer, flater, gråtoner og farger som komponeres sammen for å gi mening.

Når kunnskapsstrukturer konstrueres, kan disse forstås som personlige og subjektive representasjoner og forståelser av ulike fenomener. Disse fenomenene oppleves $i$ et samspill med det sosiale og en verden vi lever og virker i. Når disse representasjonene kombineres og utvides, konstrueres ny kunnskap. Tenkning og kognitive prosesser er en byggeprosess hvor kunnskapen kan forstås som bygningen. Visuell tenkning forstår jeg som mentale prosesser der kunstneriske, skapende og kroppslige prosesser har vært fremtredende som drivere av den visuelle tenkningen.

Hvordan henger ting sammen, hvordan kan ulike deler av det jeg jobber med, settes sammen, hvordan skape en arkitektur og en komposisjon av de ulike komponentene som er i spill i de forskjellige prosjektene og deler av prosjektene? Alle disse spørsmålene vil for meg være nødvendig å tegne ut visuelt samtidig som jeg tenker og skriver frem en konseptuell forståelse for det jeg behandler og problematiserer. Gjennom dette peker jeg på det visuelle som arbeidsverktøy i kampen med å forstå og forklare, heller enn at det er statisk konkluderende representasjon av en viten som allerede er der. Gjennom en kroppslig fornemmelse trer en bevissthet om hvordan ulike komponenter henger sammen, frem. Min 


\section{A. Letnes}

kroppslige slåsskamp materialiseres som strev, svette, uro og fremgang, og når gjennombruddene i forståelse kommer, er det visuelle svært fremtredende. Jeg ser det hele for meg i en slags visualisering som driver tenkningen og setter den $\mathrm{i}$ bevegelse. Samtidig som visualiseringen gjør det hele synlig for meg i en form for en ryddeprosess, blir sluttresultatet en visuell fremstilling som er med på å sette de ulike komponentene sammen. På denne måten gir det visuelle tenkningen en kraft som er en katalysator og en nødvendighet for forskningsprosjektets fremdrift.

A/r/tografisk eksempel 2 - Felles mediering og re-mediering - En annen forskers øyne

A/r/tografisk eksempel 2 er representert med forskningsprosjektet «Kunstner eller lærer». Dette er et forskningsprosjekt hvor jeg kom inn i ettertid for å visualisere forskningsresultater for en annen forsker; i dette posisjoneres jeg som kunstner (grafisk designer).

Modell

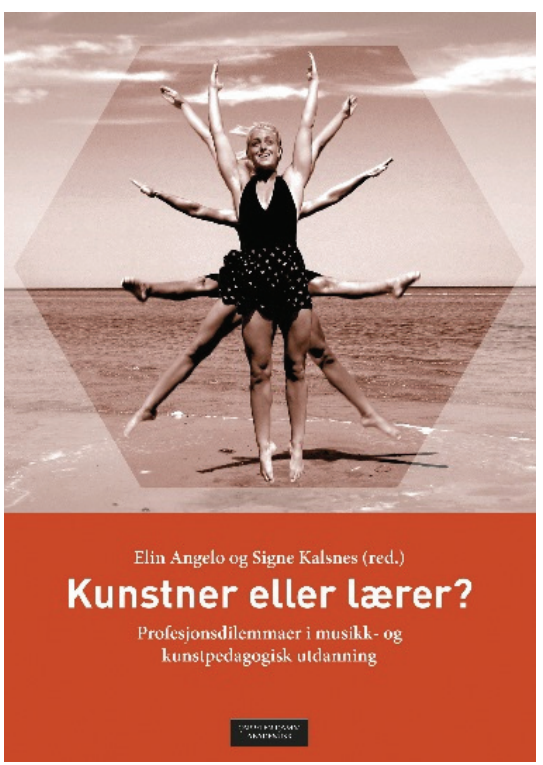

Figur 5. Omslag. (Letnes i Angelo, 2014)
Retrospektiv logg

Elin Angelo er en forskerkollega av meg, og vi har stadig lange og gode turer hvor vi prater om alt mellom himmel og jord. Disse turene kaller vi for tankeganger. Tankeganger er turer hvor vi tenker og kommuniserer samtidig som vi går. På mange av disse turene har Elin pratet om et av sine forskningsprosjekter, hvor hun har undersøkt ulike roller en musikklærer har i utøvelse av sitt yrke. Hun forteller at hun ser for seg en person som må strekke seg ut mot alle mulige retninger. Hun ønsket at vi skulle forsøke å fremstille noe visuelt av det hun vil formidle gjennom sin forskning. Dette slik at leserne av boken hun jobbet med, skulle kunne se for seg det hun hadde funnet ut. Vi satte oss ned og jeg forsøkte å tegne frem hennes forståelse. Gjennom å la ideene hoppe frem og tilbake mellom oss kommuniserte vi oss frem til en visuell fremstilling som stemte med hennes oppfatning av hvordan det hele hang sammen. Resultatet ble så fotografert, hvor en danser representerer hvordan en kunstner strekker seg i mange retninger i spørsmålet om han/hun er kunstner eller lærer. Fotoene er så manipulert i Photoshop for å visualisere at man kan trekkes i mange retninger samtidig, og det hele er plassert inn $i$ en sekskant som skal lede tankene mot den didaktiske relasjonsmodellen. Det hele ble fotografert på en strand hvor føttene til danseren ligger i horisontlinja. 
Modell

Figur i boken

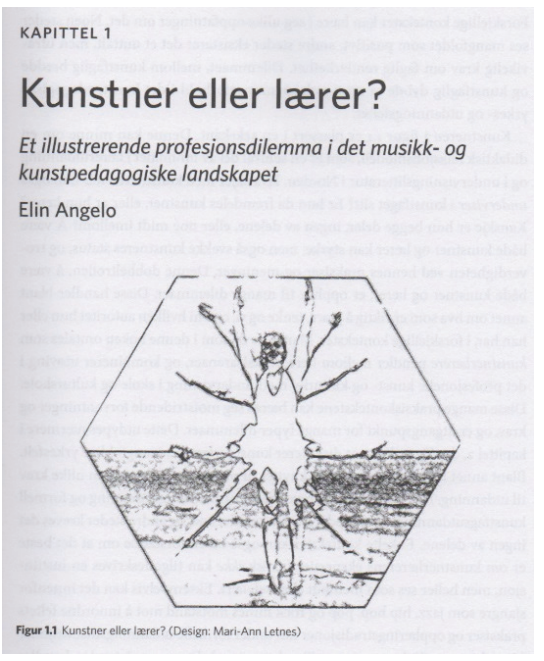

Figur 6. Kunstner eller lærer? (Letnes i Angelo, 2014)
Retrospektiv logg

Mari-Ann, kan du abstrahere den litt for meg så det blir litt mer rom for tolkning inn i modellen, slik at den blir en figur heller enn et bilde? Dette spørsmålet fikk jeg av Elin da hun satt og skrev innledningskapitlet til boken jeg hadde laget forsiden til. feg har lyst til å bruke den som en modell inn $i$ boken og der trenger den å vare litt mer åpen og ikke så konkret, fortsetter hun. Jeg satte meg ned med Photoshop og jobbet videre med bildet som danner utgangspunkt for forsidens layout. Jeg gjorde det om til sort-hvitt og la på ulike filtre som fjernet noe av detaljene i bildet. Nå ble sekskanten tydeligere, og danseren ble mer utydelig. Det var akkurat dette Elin ville ha, og hun fortsetter å skrive innledningen, nå med nye oppdagelser i materialet sitt. Hun skriver så frem en forståelse av modellen som er skapt av oss i fellesskap, og modellen forteller henne noe nytt om hennes materiale. I innledningen på boken redegjør hun for modellen, og denne modellen blir så til et nytt innledningskapittel. Her kommuniserer hun sin forståelse både skriftlig og gjennom denne nye modellen.

\section{Visuell kommunikasjon - delaspekt av visualiseringens kraft}

Innledningskapitlet i boken til Elin starter med: Bokens forside er her blitt til figur 1.1. «Midt i denne figuren er en danser. Hun kunne like gjerne vært musiker, billedkunstner eller skuespiller, og symboliserer kunstnere generelt, uavhengig av kunstfag [...]" (Angelo, 2014, s. 21).Videre i kapitlet går hun inn på sekskanten, den filosofiske dimensjonen, den sprudlende kunstneren, enkeltindividet og fellesskapet. Gjennom hele kapitlet kommer hun tilbake til elementer som den nye figuren forteller henne. Kommunikasjon er en prosess som involverer deling av meningsinnhold og informasjon med andre. Vi veksler og utveksler meningsinnhold og meldinger gjennom en stor variasjon av kanaler. Det vi tar imot, tolkes og rekonstrueres. På denne måten handler visuell kommunikasjon både om denotasjon og konnotasjon. Visuell kommunikasjon forstås som en vedvarende prosess hvor meningsinnhold blir utvekslet mellom individer. I det daglige kommuniserer vi visuelt både bevisst og ubevisst i form av klær og de ulike artefaktene vi bruker, som f.eks. en mobiltelefon. I forskning brukes visuelle representasjoner i den hensikt å strukturere og presentere et innhold. Visuelle representasjoner som presenterer prinsipper, sammenhenger, eksperimenter, undersøkelser og funn styrker tekstens kommunikasjonseffekt. Effektive visuelle representasjoner er kraftige kommunikative redskaper både i forskningsformidling og i populærvitenskapelig formidling. Det å skape visuelle representasjoner handler både om kommunikasjon med en selv og egen forståelse, samt å formidle denne forståelsen til omverdenen.

I den retrospektive loggen presentert i dette eksempelet, beskriver jeg hvordan jeg oppfatter at det visuelle fungerer som en motor for den indre kommunikasjonen hos 


\section{A. Letnes}

Elin. Når vi sammen visualiserte hennes tanker og forståelser, fikk hun tilbake en modell som satte i gang nye tanker og forståelser hos henne. På denne måten ble vår visuelle kommunikasjon en optikk som Elin kunne se sin forståelse gjennom. Denne optikken ga næring til ny og utvidet forståelse som i sin tur kunne kommuniseres med bokens lesere. Ved å bruke visuelle representasjoner i forskningstekster forsøker forskeren å «vise» heller enn å skrive frem for å «fortelle» om forskningen (Trumbo, 1999). Enhver form for representasjon bærer med seg egne konvensjoner og potensialer for ulike tolkninger og mistolkninger. Gjennom å kommunisere med visuelle representasjoner som en del av en forskningstekst, kan forskeren hjelpes videre med å etablere et rammeverk for det som skal formidles.

A/r/t-ografisk eksempel 3 - Iscenesetting av metodologisk forståelse hos masterstudenter Dette $\mathrm{a} / \mathrm{r} / \mathrm{t}$-ografiske eksempelet er representert med undervisning av masterstudenters forskningsdesign i emnet kunstfagdidaktisk forskning som jeg underviser i. I dette eksempelet har jeg vært posisjonert som lærer, og fokuset for eksempelet er hvordan man kan iscenesette et visuelt læringsrom.

Konkretisering

Forelesningen «Visualisering»

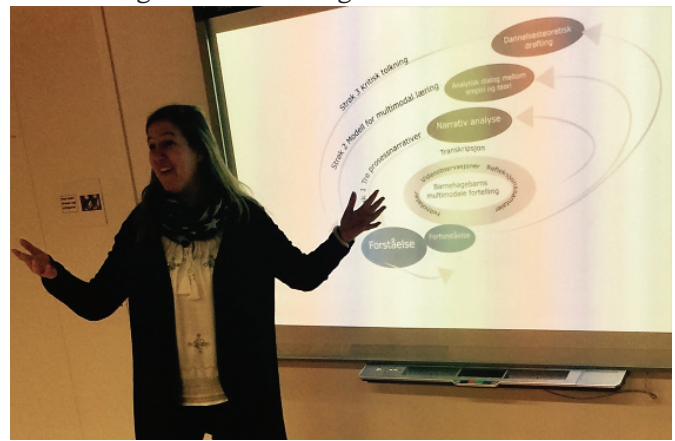

Konkretisering

Studentarbeider

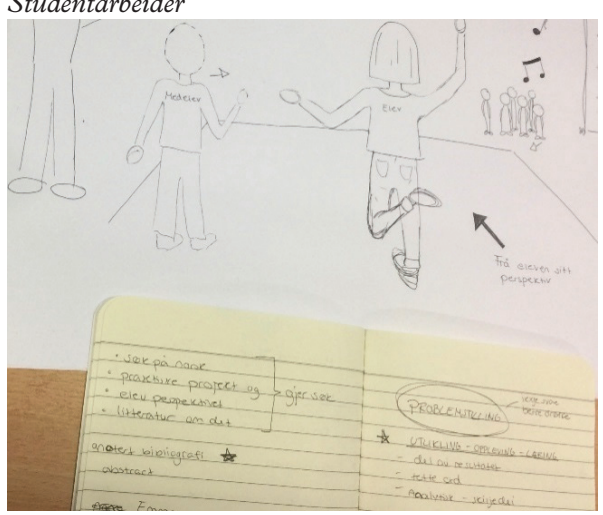

Retrospektiv logg

I masteremnet kunstfagdidaktisk forskning ved NTNU ved masterstudiet i fag- og yrkesdidaktikk og lærerprofesjon, retning kunstfag, underviser jeg om visualisering i forskningssammenheng. Fokuset i økten er å få studenter til å kunne se for seg sitt eget framvoksende forskningsdesign for masteroppgaven og hvordan deres undersøkelseselementer henger sammen. I denne forelesningen har jeg et fokus på hvordan visuelle modeller og figurer kan være med på å gi innhold i en tekst. Fremgangsmåten min er å vise frem visuelle figurer og hvordan disse kan leses.

\section{Retrospektiv logg}

Som en del av økten får studentene anledning til å tegne ut sitt eget prosjekt. En av hovedutfordringene med masterstudentenes inngang til

forskningsmetode synes for meg å være det å skifte fra å ha et øvet lærerblikk og over til et forskerblikk. Gjennom å la dem få bruke visuell fremstilling på hva i prosjektet som er undervisningsmetode og hvilke elementer som er forskningsmetode førsøker jeg å legge til rette for et læringsrom hvor studentene kan gjøre refleksjoner knyttet til de tre ulike rollene det å «forske med kunsten» kan innebære Dette ble markert i korrekturen. Her er det noe som ikke stemmer, Maria. 


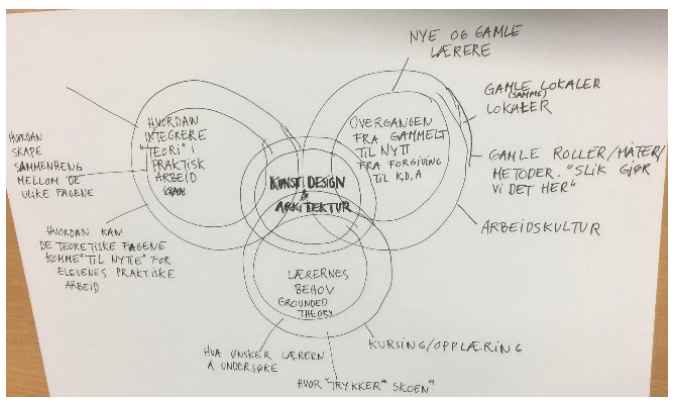

Figur 7. Studentarbeid forskningsdesign.

\section{Visuell lcering - delaspekt av visualiseringens kraft}

Et av arbeidskravene i dette emnet er en akademisk poster. Eksamensinnleveringen er (blant annet) en prosjektbeskrivelse. Disse to komponentene som dette emnet (blant annet) består av, handler om å legge til rette for at studentene kan synliggjøre hvordan de tenker seg prosjektet sitt gjennomført. Gjennom den akademiske posteren trenger studentene å «tegne ut» prosjektet sitt, hvorpå de i prosjektbeskrivelsen forklarer med tekst og modeller hvordan prosjektet er tenkt gjennomført. Bruk av visuelle representasjoner som en del av kollaborerende eller multidisiplinære undersøkelser er et viktig moment som masterstudenter trenger å lære. I dette emnet ønsker vi å legge til rette for at studentene kan lære å bruke visuelle representasjoner som et interaktivt verktøy, samt undersøkelse av hvilke affordanser som ligger i visuelle representasjoner. Affordans handler om hva ulike modaliteter eller de ulike semiotiske ressursene bærer i seg av muligheter og begrensninger for hva de passer til å uttrykke (Tønnessen, 2010). Affordans er et engelsk begrep, og man har hatt vanskeligheter med å finne et godt norsk ord for dette begrepet. På svensk har man oversatt begrepet med «meningserbjudande», som på norsk vil være det samme som meningspotensial/ meningstilbud. I sitt rammeverk bruker Trumbo (1999) Blooms taksonomi (Bloom, 1956) for klassifisering av læring når han forklarer hvordan den visuelle læringsprosessen foregår. Dette er kunnskap, forståelse, anvendelse, analyse og syntese, som av Trumbo blir omgjort til visuell kunnskap, visuell forståelse, visuell anvendelse, visuell analyse og visuell syntese. Visuell kunnskap handler om bruk av visuell representasjon for å gjenkalle konsepter og om å organisere konsepter eller prosesser gjennom visuell representasjon. Visuell forståelse handler om evnen til å tolke visuell representasjon og evne til å konseptualisere gjennom bruk av visuell representasjon. Gjennom hele undervisningsøkten om visuell fremstilling i forskning er jeg i dialog med studentene om hvordan de ulike modellene jeg viser, kan «leses». Dette gir dem visuell trening som kan være nyttig både i lesing av forskningstekster og i skriving av masteroppgaven. Visuell anvendelse handler om bruk av notasjon, bruk av figurer, grafer, diagram og andre grafiske uttrykk, valg av passende mode i en visuell representasjon, tekniske ferdigheter, bruk av designprinsipper og persepsjon, samt bruk av passende metode for visuell representasjon. I undervisningsøkten som er presentert gjennom 


\section{A. Letnes}

den retrospektive loggen over, får studentene mulighet til å tegne ut konseptet rundt prosjektet sitt visuelt. Her undersøker studentene hvordan de ulike komponentene i deres undersøkelse kan henge sammen. Visuell analyse og syntese handler om bruk av visuelle representasjoner for å synliggjøre forskningsprosesser, å inkorporere tekst eller fortellinger og visuelle representasjoner gjennom en multimodal fremstilling. Visuell evaluering handler om å gjøre vurderinger basert på visuelle representasjoner, vurdering av mulighetene som ligger i bruk av visuelle representasjoner og avgjøre effekten av visuelle representasjoner. Som en del av arbeidskravet i emnet kunstfaglig forskning har studentene en posterpresentasjon. Her får studentene trening i å gi tilbakemelding på det medstudenter har gjort. Med dette får de trening i visuell evaluering. Visuell laring har to hovedkomponenter: forståelse for visuelle representasjoners plass som representasjonsformer i konkretisering av faglig innhold, samt forståelse og kunnskap om hvordan man kan tolke mening fra visuelle representasjoner. Visuell læring inneholder en dobbelthet: visuelle representasjoner som semiotiske ressurser når en underviser eller iscenesetter for læring, kan konkretisere et faglig innhold, eller visuelle representasjoner kan brukes som et læringsverktøy av den lærende i den hensikt å organisere et faglig innhold som visuelle konkrete eller mentale bilder.

\section{A/r/tografisk forståelse av visualiseringens kraft på tvers av tre praksiser}

Å omskape intuitive mønster

Vitenskapelige oppdagelser i kvalitativ forskning skjer gjennom en prosess hvor mønster gjenkjennes og utforskes, analyseres, tolkes og kommuniseres. Forskning skjer ikke gjennom faste oppskrifter eller metoder, men heller gjennom en kompleks prosess av problemløsning, mønstergjenkjenning (likheter og ulikheter) og syntetisering. Mønstrene kan være nettverk av sammenhenger mellom erfaringer, antagelser, observasjoner, målinger og "fakta». Vitenskap og forskning handler for det meste om kampen med å omskape intuitive mønster til noe endelig og definitivt (Loehle, 1994). Like fullt vil dette endelige og definitive kun være midlertidig frosset og fiksert forståelse situert i en sosiohistorisk kontekst, som kanskje ikke lar seg overføre i andre situasjoner. Hvordan disse mønstrene som vi konstruerer og blir bevisst, skal kommuniseres, fremstilles og tenkes på, kan være forskjellig fra forsker til forsker. Å konstruere og kommunisere visuelt er én måte å drive forskningen fremover på. $\AA$ A konstruere og kommunisere visuelt innebærer bruk av egen visuell literacy. Visuell literacy er en kompleks kroppslig og kognitiv handling. Jeg har visualisert og konseptualisert hvordan jeg ser visuell literacy som en sammenstilling av visuell tenking, visuell læring og visuell kommunikasjon (se figur 8). For meg har den visuelle tenkingen vært særlig sentral som metodologiske grep i forskningsprosessen, mens det for andre kan være andre modaliteter som driver prosessen fremover. De visuelle ferdighetene kan utvikles gjennom øving og praksis, og de kan videreutvikles til å bli nyttige læringsstrategier. A konstruere mening gjennom visuelle uttrykk innebærer at det visuelle uttrykket kan «leses» av andre. Forestillingen om at bilder kan «leses», 


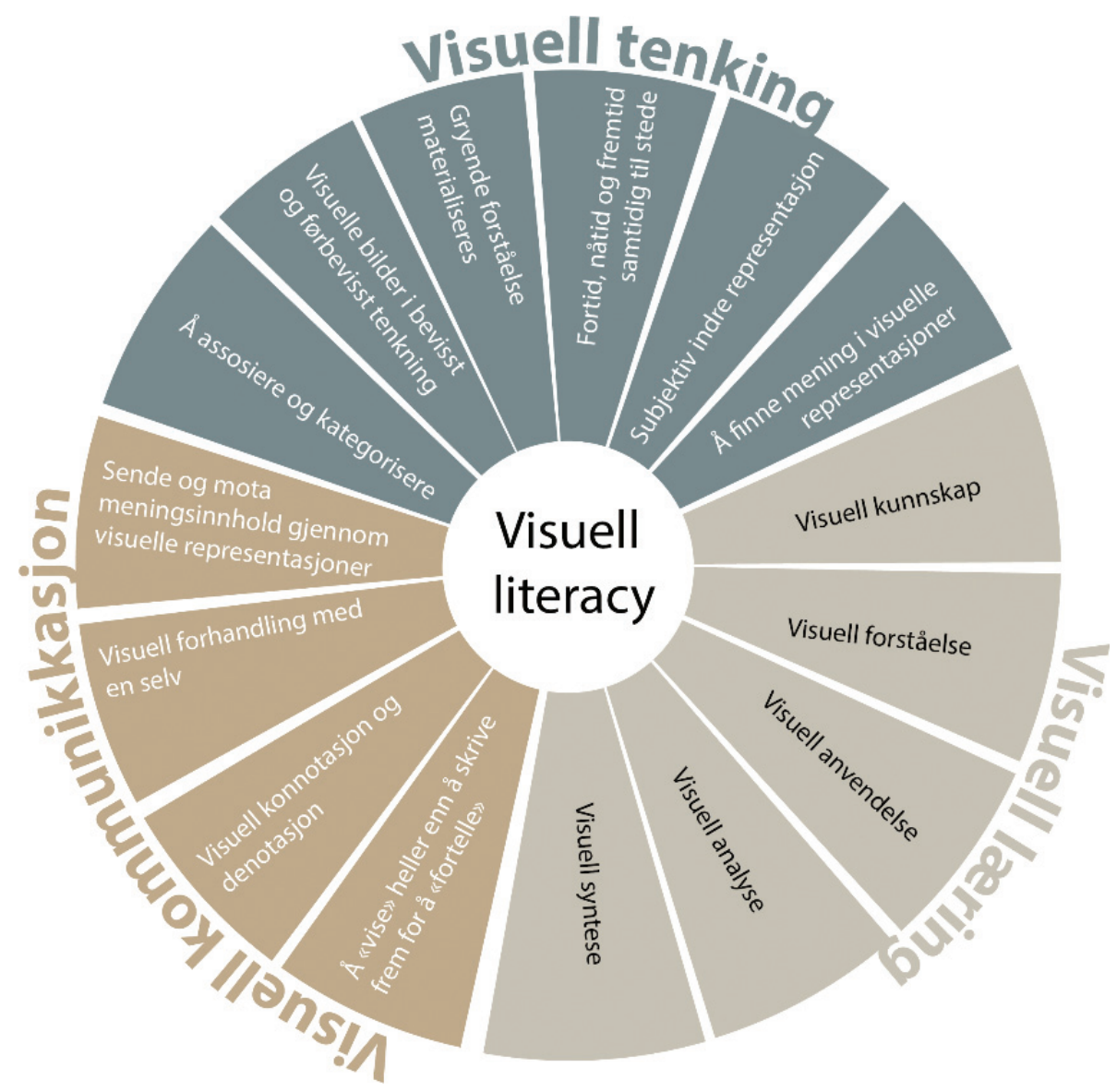

Figur 8. Visuell literacy. (Letnes, 2017)

innebærer at det finnes et visuelt språk som består av ulike «vokabular». Det visuelle vokabularet kan karakteriseres som grunnleggende visuelle virkemidler som punktet, linjen, flaten og volum, samt farge. Dette er grunnleggende elementer som komponeres sammen for å forstå, konseptualisere og kommunisere et meningsinnhold.

\section{Ulike modaliteter som omdreiningspunkt}

Jeg tenker visuelt, og det har vært en styrke for meg. Forståelsen av den verden vi er i, kan artikuleres gjennom mange ulike medieringer og modaliteter, det være seg det visuelle, det kroppslige, det auditive eller andre modaliteter. På denne måten løftes ulike modaliteters muligheter inn i forskningen som aktuelle representasjonsformer både som kunnskapskonstruksjon og kunnskapskommunikasjon.

Her vender jeg tilbake til forskningsspørsmålet som har ledet meg gjennom arbeidet med denne artikkelen: Hvordan kan visualisering ha en sentral rolle $i$ kunnskapskonstruksjon, meningsskaping og meningskommunikasjon? 


\section{A. Letnes}

Et sentralt element i denne problemstillingen er kunnskapskonstruksjon. Med dette dukker spørsmålet «hva er kunnskap?» opp. Molander (2009) peker på at det er vanlig å se på kunnskap som knyttet til en dualisme mellom det kunnskapende subjekt i det indre og kunnskapens formål i ytterverden. Denne forståelsen av kunnskap baseres på at individet skaper en indre forståelse av en ytre verden, hvorav den indre kunnskapen er en avbildning eller en representasjon av den ytre verden. Kunnskap blir med dette tingliggjort, hvor kunnskap sees på som en objektiv størrelse og det mest sentrale, mens den kyndige personen er mindre sentral. I sosialkonstruksjonistiske teorier fremheves at den sosiale virkeligheten skapes gjennom vår interaksjon med hverandre. Med dette skapes og konstrueres kunnskapen ikke om virkeligheten, men i virkeligheten gjennom kommunikasjon og språket vårt. I et utvidet språksyn representerer også det visuelle en del av språket vårt, og i dette blir den visuelle måten å konstruere og representere kunnskap på en del av kunnskapen. Med dette flyttes det visuelle fra å være form til å bli innhold. Jeg bruker å si til mine studenter at det er innhold i form også. Med dette ønsker jeg å tydeliggjøre (for studentene) at det også er viktig å ha fokus på formsiden av et uttrykk. Måten ulike komponenter settes sammen, dette være seg i bilder, fagtekster eller i kunstuttrykk som en dans, får betydning og blir en del av meningsinnholdet i disse uttrykkene.

I artikkelen har jeg brukt mine tre a/r/tografiske posisjoner som utøver (grafisk designer), forsker og lærer for å undersøke hvordan visuelle representasjoner virker i forsknings- kommunikasjons- og læringsprosesser. Dette er en analytisk fremstilling av en kompleks virkelighet da alle tre komponentene av visuell literasitet er til stede $\mathrm{i}$ alle tre $\mathrm{a} / \mathrm{r} /$ tografiske eksemplene, men jeg opplever at det som står i forgrunnen, skifter på å være aktivt på tvers av eksemplene. Figur 8 er en visualisering av det jeg i en retroperspektiverende analyse har gjenkjent som en drivkraft gjennom hele min utøver-, forsker- og lærervirksomhet. Med dette ønsker jeg å sette søkelyset på potensialet som ligger i å ha større trykk på en multimodal inngang til forskningsmetodologi. Visualisering kan gjøres både for en selv og i kommunikasjon med andre. For det første handler det om å 'tegne frem' en forståelse for seg selv. Gjennom å skissere og tegne ut sammenhenger kan man se for seg hvordan ulike fenomener som erfares henger sammen, og med dette kan en forståelse for væren i verden vokse frem. For det andre kan det handle om å interagere med andre i den hensikt å kommunisere en forståelse. For det tredje kan en tenke seg en mer abstrakt visualisering som handler om de mentale bildene man skaper i sine tanker, som for eksempel å lage seg visuelle huskeregler. Visuell tenkning, visuell kommunikasjon og visuell læring har dannet strukturen i teksten og gjennomgangen av hvordan det visuelle kan virke som en kraft som driver forskning fremover, så vel som i undervisning, læring og kommunikasjon av meningsinnhold. Gjennom å anerkjenne at det fins mange måter å konstruere og kommunisere kunnskap på, tror jeg at et større trykk på en multimodal inngang til kunnskap i utdanningsløpet generelt og i forskningsutdanningen spesielt, vil legge til rette for en rikere og dypere forståelse for væren i verden. På denne måten vil ulike typer representasjoner brukes for å øke konseptuell forståelse og for å forsterke kommunikasjonen. 


\section{Visualisering som drivkraft i kunnskapskonstruksjon}

\section{Forfatteromtale}

Mari-Ann Letnes (ph.d.) er førsteamanuensis i pedagogikk og kunst \& håndverk ved Institutt for lærerutdanning, NTNU. Hun har gjennomført flere forskningsprosjekter knyttet til barns praktiske skapende arbeid og kunstfaglige læreprosesser i skole og i barnehage, samt barns bruk av digital teknologi i skapende prosjekter. Hun deltar i ulike europeiske forskningsprosjekter og forskningsnettverk. Hun har bred undervisningserfaring fra grunnskolen, kulturskolen, videregående og lærerutdanning i faget kunst og håndverk, samt undervisning på master for kunstfagdidaktikk. Hun er nå prosjektleder for DigGiLU et utviklingsprosjekt som har til hensikt å legge til rette for lærerstudenters profesjonsfaglig digital kompetanse. Prosjektet er tildelt 22 millioner fra kunnskapsdepartementet, og har en varighet på tre år (2018-2020). Hun har utgitt artikler, bøker og deltatt som invitert foredragsholder på flere konferanser i Norge og Sverige samt bidratt med paperpresentasjoner på internasjonale og nasjonale konferanser i inn- og utland.

\section{Referanser}

Alvesson, M. \& Sköldberg, K. (2008). Tolkning och reflektion: vetenskapsfilosofi och kvalitativ metod. Lund: Studentlitteratur.

Angelo, E. (2014). Kunstner eller lærer? Et illustrerende profesjonsdilemma i det musikk- og kunstpedagogiske landskapet. I E. Angelo \& S. Kalsnes (red.), Kunstner eller larer? : profesjonsdilemmaer $i$ musikk- og kunstpedagogisk utdanning (s. 21-41). Oslo: Cappelen Damm Akademisk.

Avgerinou, M. \& Ericson, J. (1997). A Review of the Concept of Visual Literacy. British Fournal of Educational Technology, 28(4), 280-291. doi:10.1111/1467-8535.00035

Barthes, R. (1977). Rhetoric of the Image. I T. S. Heath. (red.), Image, Music, Text (s. 32-51). New York: Hill and Wang.

Bendiksen, S. A. (2017). Tegnmakerens skrivelek - En a/r/tografisk studie av en fireårings tegnmaking i mulighetsrike verksteder. InFormation. Nordic fournal of Art and Research, 6(1), 1-22.

Bloom, B. (red.) (1956). Taxonomy of Educational Objectives, Handbook I: Cognitive domain. New York: Longman.

Boorstin, D. J. (1992). The creators: A History of Heroes of the Imagination. New York: Random House.

Bradent, R. A. \& Hortinf, J. A. (1982). Identifying The Theoretical Foundations of Visual Literacy. Fournal of Visual Verbal Languaging, 2(2), 37-42. doi:10.1080/23796529.1982.11674354

Dwyer, F. M. (1972). A guide for improving visualized instruction. State College, PA: Learning Services.

Halliday, M. A. K. (1978). Language as social semiotic: the social interpretation of language and meaning. London: Edward Arnold.

Kress, G. \& Van Leeuwen, T. (2001). Multimodal discourse: the modes and media of contemporary communication. London: Arnold Hodder.

Leavy, P. (2009). Method meets art : arts-based research practice. New York: Guilford Press.

Lemke, J. L. (1998). Multiplying meaning:Visual and verbal Semiotics in scientific text. I J. R. Martin \& R. Veel (red.), Reading Science: Critical and Functional Perspectives on Discourses of Science (s. 87-115). London: Routledge.

Letnes, M.-A. (2014). Digital dannelse $i$ barnehagen: barnehagebarns meningsskaping $i$ arbeid med multimodal fortelling (Diss). Trondheim: NTNU, Norges teknisk-naturvitenskapelige universitet.

Loehle, C. (1994). Discovery as a process. Fournal of Creative Behavior, 28(4), 50.

Molander, B. (2009). Estetiske lärprocesser - några kunskapsteoretiske reflektioner. I F. Lindstrand \& S. Selander (red.), Estetiskea Lärprocesser (s. 227-249). Lund: Studentlitteratur.

Moritary, S. (1997). A conceptual map of visual communication. Fournal of Visual Literacy, 17(2), 9-24.

Moriarty, S. \& Kenney, K. (1995). Visual Communication: A Taxonomy And Bibliography. Fournal of Visual Literacy, 15(2), 7-50. doi:10.1080/23796529.1995.11674502

Ricardo, M.-V. \& Joaquín, R. (2012). Quality Criteria in Visual A/r/tography Photo Essays: European Perspectives After Daumier's Graphic Ideas. Visual Arts Research, 38(2), 13-25. doi:10.5406/visuartsrese. 38.2.0013

Springgay, S. \& Irwin, R. (2005). A/r/tography as Living Inquiry Through Art and Text. Qualitative Inquiry, 11(6), 897-912.

Trumbo, J. (1999). Visual Literacy and Science Communication. Science Communication, 20(4), 409-425. doi:10.1177/1075547099020004004

Tønnessen, E. S. (2010). Tekstpraksis i bevegelse. I E. S. Tønnessen (red.), Sammensatte tekster: barns tekstpraksis (s. 10-22). Oslo: Universitetsforlaget. 


\section{A. Letnes}

Wileman, R. E. (1980). Exercises in visual thinking. New York: Hastings House Publishers.

Yore, L. D. \& Treagust, D. F. (2006). Current Realities and Future Possibilities: Language and science literacy-empowering research and informing instruction. International fournal of Science Education, 28(2-3), 291-314. doi:10.1080/09500690500336973

Østern, T. P. (2017) Å forske med kunsten som metodologisk praksis med aesthesia som mandat. fournal for Research in Arts and Sports Education, Special Issue: "A forske med kunsten”, Vol. 1 (2017), 7-27. 